ELORE (ISSN 1456-3010), vol. $13-2 / 2006$.

Julkaisija: Suomen Kansantietouden Tutkijain Seura ry.

[http://cc.joensuu.fi/ /oristi/2_06/ran2_06.pdf]

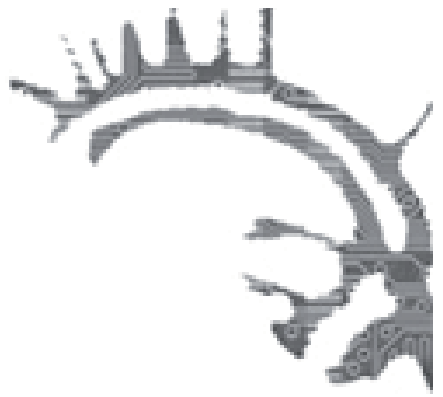

\title{
Ammattina PILKKARUNOILIJA
}

\author{
Pälvi Rantala
}

\section{SE TEKI RUNON KENESTÄ HALUSI}

"Kun ilkkurunoja tekee ja hävittömiä sanoja käyttää, niin niissä on mainio." Näin kertoi poliisi Esko Käräjäoja Samuli Paulaharjulle Haapavedellä vuonna 1917. (SKS, KRA Paulaharju, Samuli 2668-26804, 1935.) Puheena oleva "ilkkurunojen" tekijä oli Viina-Matti, Matti Viinamaa. Matti oli omanlaisensa: pukeutui runokeikalle lähtiessään naisten pehmeäkankaisiin hameisiin, esiintymisasuun, ja etsiytyi sinne, missä jätkäporukalla oli varaa maksaa markka roisista pilkkarunosta. Itse Matti ei näistä runoistansa innostunut, mutta niillä tienasi hyvin. Hän teki runon pyydettäessä, mutta usein myös pyytämättä. Matille ei uskallettu naureskella, häntä jopa pelättiin. Jos hänelle sanoi pahasti, hän teki heti pilkkaavan runon, joka saattoi pilata maineen pitkäksi aikaa.

Viina-Matti ei kuitenkaan ole ollut ainoa pilkkarunojen tai -laulujen tekemisellä elatuksensa hankkiva. Tässä artikkelissa tarkastelen neljän eri aikoina eläneen ja eri puolilla Suomea asuneen pilkkarunoilijan elämää ja tuotantoa. Pilkkarunoilija oli useimmiten rahvaanrunoilija, joka pyytämällä tai spontaanisti teki pilkkaavia runoja ja lauluja. Pilkkarunoilijalle oli yhteisössään vakiintunut jonkinlainen taiteilijan, komeljanttarin tai esiintyjän rooli, johon liittyi usein myös hiven traagisuutta. (Ks. Kukkonen 1975, 16-18.) Näkökulmani on runoilijoissa ja runoissa osana aikaansa ja yhteisöään. Keitä runoilijat olivat ja mihin heidän pilkkansa kohdistui? Millaisissa tilanteissa runot syntyivät, ja miten ne ovat vaikuttaneet yhteisöönsä? Millainen rooli pilkkarunoilijalla oli yhteisössään, ja mihin ihmiset ovat tarvinneet ammattimaisia pilkkarunoilijoitaan? Näihin kysymyksiin vastaan analysoimalla näiden neljän runoilijan tekstejä siten, että lukija saa kokonaiskuvan sekä runoista että siitä, millaisissa tilanteissa ja minkä vuoksi runoilijat niitä sepittivät. Runojen lisäksi käytän aineistona runoilijoista eri aikoina tallennettuna kertomuksia ja muita elämäkertatietoja.

Tarkastelemani runoilijat ovat Vihta-Paavo (Paavo Korhonen), Kalkkimaan pappi (Pietari Herajärvi), Juho Tanholin ja Viina-Matti (Matti Viinamaa). Rautalammilla vuonna 1775 syntynyt ja vuonna 1840 kuollut Vihta-Paavo saavutti legendaarisen 
runoilijan maineen jo eläessään. Alatorniolla vuosina 1830-1885 eläneen Kalkkimaan papin elämästä tiedetään vähän, mutta oletetaan ja kerrotaan sitäkin enemmän. Juho Tanholin (1863-1928) Viitasaarelta ja Viina-Matti (1859-1936) Haapavedeltä ovat joukon nuorimmat.

\section{RAHVAANRUNOILIJAT PILKKARUNOJEN TEKIJÖINÄ}

Pilkkarunoista on Suomessa kirjoitettu jonkin verran, lähinnä osana rahvaanrunoutta käsitellyttä tutkimusta (esim. Häggman 1974; Kuusi 1963a; Kukkonen \& Sihvo 1975; Laurila 1956). Maaseudun koulua käymättömien tai vain vähän oppia saaneiden rahvaan- tai talonpoikaisrunoilijoiden tuotoksia on arvioitu suhteessa kalevalaiseen kansanrunoon ja toisaalta oppineen sivistyneistön kirjoittamaan taiderunouteen. Runojen kirjallisesta kulttuurista saaneiden vaikutteiden, yksilöllisten piirteiden ja arkisten aiheiden takia tutkijat eivät ole pitäneet rahvaanrunoutta yhtä arvokkaana kuin vanhaa kalevalamittaista, suullisesti periytynyttä runoutta. (Kurki 2004, 69; Piela 1997, 16.) Tämän vuoksi rahvaanrunoilijoiden tuotantoa on säilynyt eri tavoin ja vaihtelevassa määrin. (Kansanrunouden ja -perinteen keruusta ja ohjeistuksista ks. SKS, KRA. Keruuohjeita 1847-1961, 1-24; Fingerroos 2004, 20-21; Peltonen 2004; Pöysä \& Timonen 2004.) Samoin kuin suullisen ja kirjallisen perinteen välimaastoon sijoittuvien kansankirjoittajien ja -kerääjien, myös rahvaanrunoilijoiden paikan määrittely on koettu ongelmallisena. Määrittelyongelmat eivät kuitenkaan ole niinkään vaivanneet itse runoilijoita kuin kerääjiä ja tutkijoita (ks. Kauranen tässä julkaisussa; Kukkonen 1975, 10-12; Kurki 2004, 69-71; Könönen 1989, 203; Sihvo 1975, 49-50.)

Tässä artikkelissa tavoitteenani ei ole määritellä pilkkarunoilijoiden ja heidän tuotostensa paikkaa taiderunon ja kansanrunon välillä tai arvioida runojen laatua vaan näkökulmani on pilkkarunoissa ja runoilijoiden toiminnassa osana yhteisön sosiaalista kanssakäymistä ja kommunikointia. Yhteisöllisestä näkökulmasta pilkkarunoudesta ovat kirjoittaneet esimerkiksi Pertti Anttonen pro gradu -tutkielmassaan Rituaalinen pilkeka länsi-inkeriläisissä kylähä̈ssä (1987) ja Kustaa H. J. Vilkuna artikkelissaan Herotes oli koira: bumoristinen pube rikoksena (2000a).

Kuten useimpien rahvaanrunoilijoiden, myös Paavo Korhosen, Pietari Herajärven, Matti Viinamaan ja Juho Tanholinin tuotanto pitää sisällään hyvin erityyppisiä runoja, joista pilkkarunot muodostavat vain osan. Artikkelissani he kaikki kuitenkin esiintyvät pääasiassa osa-aikaisina tai päätoimisina pilkkarunoilijoina. Käytän artikkelini pilkkarunoilijoista heidän "taiteilijanimiään": Pietari Herajärveä kutsuttiin Kalkkimaan papiksi kotipaikan ja tekemiensä pilasaarnojen vuoksi, Paavo Korhosesta käytetään usein nimitystä Vihta-Paavo sen talon mukaan, jossa hän asui. Matti Viinamaa tunnetaan, myös asuinpaikkansa mukaan, yleisesti Viina-Mattina, Juho Tanholinilla ei tiedetä olleen erikseen runoilijanimeä. Pohdin nimien käyttöä pitkään: kenties olisi arvostavampaa käyttää kaikista sukunimeä, mutta toisaalta yksikään lempinimi ei ole halventava. 


\section{Pälvi Rantala}

\section{RUNOT JA NIIDEN SYNTYTILANTEET}

Olen valinnut analysoitaviksi neljän runoilijan tallennetuista teksteistä ne runot, joiden olen katsonut pilkkaavan joko tiettyä henkilöä, ihmisryhmää tai runoilijan yhteisön elämässä havaitsemaa epäkohtaa. Mukana on yhteensä 66 runoa, joista Kalkkimaan papin tekemiä 20, Vihta-Paavon 11, Viina-Matin 30 ja Tanholinin 9. Analyysiä ja runojen valikointia on vaikeuttanut se, että esimerkiksi Vihta-Paavon joistain runoista on ajankohtaa ja tilannetta tuntemattoman vaikea päätellä, ovatko ne pilkkarunoja vai yleisesti asian tilaa kuvaavia ja valittelevia. Kalkkimaan papin ja Viina-Matin säilyneistä runoista suuri osa on pilkkarunoja, kun taas Tanholinin ja Vihta-Paavon tallennetusta tuotannosta melkoinen osa on muun tyyppistä kuten esimerkiksi juhlarunoja.

Runot jaottelin aluksi niiden aiheiden mukaan. Pilkan kohteena ovat useimmiten siveettömyys tai huonot tavat kuten tanssi, juopottelu tai seksuaalinen käytös. Myös virkamiesten tai pappien käytös tai muut yhteiskunnalliset epäkohdat kuten liian suuret verot tai kulkurin huono kohtelu ovat suosittuja pilkan aiheita. Suuri osa runoista kohdistuu nimeltä mainiten tiettyyn henkilöön. Pilkkarunojen ajankohtaa tai syntytilannetta ei kaikissa tapauksissa tiedetä, mutta useimpien runojen synnystä on kuitenkin olemassa joitain kertomuksia. Päädyinkin jaottelemaan runot kolmeen ryhmään sen mukaan, minkä tyyppisissä tilanteissa ja minkä vuoksi ne on tehty.

Ensimmäisen ryhmän muodostavat tilatut tai eri tilanteissa pyydetyt, tiettyä henkilöä koskevat runot. Tämän ryhmän runot ovat usein hyvin seksuaalisväritteisiä, jopa rivoja. Toiseen ryhmään kuuluvat spontaanisti ärtymyksen tai huonon kohtelun seurauksena syntyneet tunteen purkaukset. Kolmantena ryhmänä ovat yhteiskunnallisia oloja tai ihmisten käytöstä ja sen epäkohtia, esimerkiksi siveettömyyttä käsittelevät runot, joiden syntytilannetta ei yleensä tiedetä. Runojen ryhmittely voisi olla muunkinlainen, ja jotkut runot voisivat kuulua kaikkiin ryhmiin. Jaottelulla kuitenkin pyrin luomaan kokonaiskuvan runoista. Koska runoja on tekijöiltään mukana erilainen määrä, en lähde pidemmälle vertailemaan heidän tuotantoaan keskenään.

\section{RUNOJEN SÄILYMINEN}

Runoja on talletettu sekä runoilijoiden elinaikana että heidän kuolemansa jälkeen, ja suuri osa runoista on myös julkaistu. Vihta-Paavo on säilyttänyt arvonsa runoilijana parhaiten halki vuosien. Hänen tuotannostaan pilkkarunot muodostavat vain pienen osan. Vihta-Paavon runoja on säilynyt runoilijan itsensä, kotiseudun oppineiden sekä kirjoitustaitoisten kansanmiesten ja suvun jäsenten käsikirjoituksina, joita on tallennettu Suomalaisen Kirjallisuuden Seuran kirjallisuusarkistoon. Tieto runojen levinnäisyydestä ja kokonaismäärästä on jäänyt satunnaiseksi, kuten on kaikkien muidenkin pilkkarunoilijoiden kohdalla. (Ks. Makkonen 2001.) Vihta-Paavon runot ja laulut on painettu Elias Lönnrotin toimittamaan kokoelmaan jo vuonna 1848, ja uusi painos runoista ilmestyi Sirkka Makkosen kokoamana ja kommentoimana vuonna 2001.

Kalkkimaan pappi ja Viina-Matti ovat jääneet elämään paitsi runojensa, myös omituisen käytöksensä ja kylähullun roolin ansiosta. Suhtautuminen heidän runotuo- 


\section{AMMATTINA PILKKARUNOILIJA}

tantoonsa on vaidellut ajan myötä, heidät on tulkittu milloin hullun ja viisaan rajalla keikkuvaksi kummajaiseksi, milloin oivaksi sanankäyttäjäksi. Viina-Matti kirjoitti nuorempana runonsa paperille, mutta useat joutuivat huonon säilytyspaikan vuoksi hukkaan, ja suuri osa paloi mökin mukana syksyllä 1927. Hilkka Merikallio on saanut tallennettua noin kolmanneksen Matin tuotannosta vuonna 1968 kokoamaansa kirjaseen Viina-Matin veisuja, osaksi Matin itsensä, osaksi ihmisten kertomana. Joistakin runoista on vain otsikot tiedossa. (Esim. Holopainen 1995; Lehtola 1992; Rantala 2000a ja b; SKS, KRA E 75; Tirilä 1995; Viinamaa 1968; Vuento 1994.)

Kalkkimaan papin runoja ei toistaiseksi ole koottu yhteen julkaisuun, mutta niitä on ilmestynyt Pertti Vuennon ja Arvid Oukan kirjoittamissa perinnejulkaisuissa sekä lukuisissa sanoma- ja aikakauslehtikirjoituksissa. Varhaisin säilynyt runo on arkkiveisu Engelsmannein käytöksestä Oulun läänissä kesällä 1854. Kalkkimaan pappi osasi ilmeisesti kirjoittaa jonkin verran, mutta tuskin kuitenkaan kirjoitti omia runojaan ylös (ks. Kauranen 2005). Hänen runojaan ovat keränneet myös muun muassa ylioppilas Uuno Hannula vuonna 1914 ja opettaja ja kotiseutumies Jalmari Puoskari 1930-luvulla. Säkeitä monista runoista on tallennettuna paikallisten ihmisten muistelemina esimerkiksi SKS:n Kansanrunousarkiston käsikirjoitus- ja äänitearkistoon. (1)

Juho Tanholin oli ensisijaisesti kansanperinteen kerääjä, mutta kirjoitti myöhemmin myös pilkka- ja muita runoja. Tanholinin runoja on säilynyt käsinkirjoitettuina arkkeina ja lehtileikkeinä. Tanholin itse kirjoitti runojaan ylös, samoin jotkut aikalaiset. Markus Möttösen ja Päivi Tuohimetsän vuonna 1980 kirjoittamassa Juho Tanholinin elämäkerrassa on teemoiteltuna koottu hänen runojaan.

Runojen lisäksi olen käyttänyt aineistona eri aikoina ja erilaisissa yhteyksissä kirjoitettuja elämäkerrallisia sekä muita runoilijoiden elämää ja tuotoksia käsitteleviä tekstejä. Vihta-Paavosta on kirjoitettu hyvinkin paljon, mutta tässä analyysissä olen käyttänyt Elias Lönnrotin (1855-1857; 1908; 1848) Martti Haavion (1923) ja Sirkka Makkosen (2001) kirjoituksia. Viina-Matin elämästä ja runojen arvioinnista ovat mukana Samuli Paulaharjun muistiinpanot 1930-luvulta (SKS, KRA), Liisa Rentolan ja Aulis Ritolan 1980-luvulla kirjoittama kaunokirjallisen elämäkertateos Vïna-Matti, viisas mies... sekä kaksi kulttuurilehti Kaltiossa vuonna 1995 julkaistua kirjoitusta (Holopainen 1995; Tirilä 1995). Kalkkimaan papista olen käyttänyt "nimimerkki Linnasen" eli Carl Alfred Castrénin aikaiskirjoituksen (Castrén 1882) lisäksi 1970-1990-luvuilla ilmestyneitä kirjoituksia (Lehtola 1992; Oukka 1986; Vuento 1994) sekä kahta haastattelunauhoitusta (SKSÄ). Juho Tanholinin osalta pääasialliset lähteeni ovat Möttösen ja Tuohimetsän kirjoittama elämäkertateos ja Möttösen vuonna 2005 julkaisema uusittu versio elämäkerrasta. Lisäksi olen lukenut F. A. Hästeskon kirjoituksen vuodelta 1914.

\section{Pilkkarunoilijoiden elämästä}

Juho Tanholin ja Kalkkimaan pappi olivat aviottomia lapsia, perheettömiä ja kodittomia miehiä ja käytökseltään outona pidettyjä kulkijoita. Viina-Matti piti ainakin ajoittain pientä taloa, viljeli puutarhaa ja hoiti eläimiä. Hänkin pysyi poikamiehenä. 


\section{Pälvi Rantala}

Vihta-Paavo oli talollinen ja joukosta ainoa perheellinen. Kaikki pyrkivät välttelemään "normaalin" työn tekemistä ja etsimään elatuksensa muulla tavalla. (Ks. Haavio 1923; Möttönen \& Tuohimetsä 1980; Viinamaa 1968; Vuento 1994.)

Kaikkien elämään liitetään myös liiallinen alkoholinkäyttö. Viinaanmenevyys ja "nöyrän, iloisen kulkijan vapaa elämä" ovat rahvaanrunoilijoihin liitettyjä myyttejä, joissa toki saattaa olla myös todellista pohjaa (Kukkonen 1975, 16-17; Sihvo 1975, 60). Kirjoituksissa toistuu kaikkien kohdalla samojen piirteiden kuvailu: hyvä muisti, kiinnostus luontoa, historiaa ja yleensä maailman asioita kohtaan, tiedonhalu, irrallisuus yhteisöstä tai jopa sen yläpuolella oleminen henkisellä mittapuulla katsottuna. Tällainen tulkinta ei koske ainoastaan näitä neljää (ks. Kukkonen 1975, 16-17). Myös "runoilijasielujen" kuljeskelevasta elämäntavasta kerrotaan ihailevaan sävyyn (mm. Hästesko 1914).

Runoilijoiden sosiaaliset taustat ovat siis vaihtelevat, eikä niiden perusteella voi tehdä johtopäätöstä, että esimerkiksi heikko sosiaalinen asema johtaisi pilkkarunojen tekemiseen. Pilkkarunojen tekijöiden uran alkua perustellaan eri tavoin. Tanholin esitetään tietoisesti vaihtaneen ammattia paremman leivän toivossa:

Enää ei SKS saa suoraan kansan suusta kerättyjä lauluja ja leikkejä viitasaarelaiselta avustajaltaan. Tanholin tekee runonsa ja tarinansa itse. Ehkä hän laskee, että tekemällä muutaman kymmenen pennin pilkkarunon pääsee parempiin ansioihin kuin SKS:n matkarahojen turvin. (Möttönen \& Tuohimetsä 1980; Möttönen 2005.)

Tanholinin kerrottiin itse pitävän runojen tekemistä kutsumustehtävänään, isänmaallisena työnä. "Työmies on palkkansa ansainnut, niinpä Tanholinillakin on taksansa." (Möttönen \& Tuohimetsä 1980).

Kalkkimaan pappi aloitti uransa esittämällä kirkonmenojen jälkeen papin saarnan sanasta sanaan, ja vähitellen hän alkoi tehdä myös omia pilasaarnoja. Tästä hän laajensi repertuaariaan pilkkaavien runojen ja laulujen alueelle.

Jo keskenkasvuisena oppi Pietari väkeviä juomaan, ja se pahe pian lannisti kaiken hänen siveellisen pontensa. Hän heittäysi laiskuuteen ja otti ainoaksi tehtäväkseen nämä työt: 'Ensin nukkuu ja kun siinä väsyy, niin sitten lepää, ja kun siinä väsyy, niin sitten makaa, ja kun siinä väsyy, niin sitten lakkaa". Mutta siitä hän ei juuri lihonut, sen tähdenpä alkoi miettiä, miten helpoimmin ansaitsisi jokapäiväisen leipänsä. (Castrén 1882, 204-205.)

Viina-Matin runoilijanuran alku oli hyvinkin arkinen, jopa liikuttava: Matin isä teki saunassa runon, Matti oppi sen pian ja teki itse toisen perään. Pilkkarunojen tekemisen aloittamista kuitenkin kuvataan vähemmän mieltäylentäväksi. Matti oli tilannut pihaansa puun taimia, mutta kylän pojat viiltelivät rungot ja puut kuolivat. "Tällaisesta ilkivallasta Matti katkeroitui. Hän herkesi epäluuloiseksi, ja hänen runonsakin muuttuivat siivottomiksi”. (Rentola \& Ritola 1984; Viinamaa 1968.) 


\section{AMMATTINA PILKKARUNOILIJA}

Vihta-Paavon ensimmäiseksi lauluksi mainitaan useissa teksteissä Kokin virsi (esim. Lönnrot 1848, esipuhe), jossa tämä suomii virkamiesasemaansa väärin käyttäneen nimismies Johan Kockin toimintaa. Tämä oli asetettu 1700-luvun lopulla valvomaan pitäjään asetettua viinanpolttokieltoa, mutta otti lahjuksia talonpojilta, velkaantui isännille ja pantiin lopulta viralta. Aikalaislehtien luoma kuva varhaiskypsästä runoilijasta, joka puuttuu kiusalliseen tilanteeseen ja saavuttaa runollaan kansansuosion, vakiintui pian henkilöhistorialliseksi faktaksi. Oli runo Vihta-Paavon läpimurtoteos tai ei, joka tapauksessa runoilijan julkisuuskuvaan on suuresti vaikuttanut juuri kertomus siitä, miten nuori mies tölväisee taidokkaalla ja pistävällä runollaan herraksi luokiteltavaa vallesmannia. (Ks. Kuusi 1975, 83; Makkonen 2001, 295-296.)

\section{JOS RUNOA PYYDÄT: TILAUSRUNOT}

Neljän runoniekan tallennetuista pilkkarunoista suurin osa on eri tilanteissa pyydettyjä, tiettyä henkilöä tai perhettä koskevia runoja. Tämä selittää myös sitä, miksi pilkkarunoilijoita on pelätty: iva ei koske vain yleistä tilannetta vaan tähtää suoraan arkaan kohtaan, henkilökohtaisesti, nimeltä mainiten ja säälimättä. Se, ettei runoja haluta kertoa kerääjälle tai haastattelijalle, johtuu useimmiten niiden sopimattomuudesta tai siitä, että runoissa mainitaan nimeltä tuttuja henkilöitä. Kerrontaa tutkineen Anna-Leena Siikalan mukaan haastateltava usein kieltäytyy käsittelemästä joitakin aiheita, jotka kuitenkin ilmeisesti tuntee. Syyksi mainitaan laulun sopimattomuus, vähäarvoisuus tai muu vastaava. (Siikala 1984, 147; ks.myös Lehtipuro 2003, 13-14.) Ulla-Maija Peltonen taas toteaa erään kerääjän kirjoittaneen:

kertovat niin paljon roskaa, että olen monta kertaa kotiin tultuani pakoitettu polttamaan heidän tarinansa vaikka ne olenkin heidän kotonaan kohteliaisuudesta kirjoittanut. Ja luulen että Herra tohtorikin kauhistuisi jos minä kaikki kansan kertomat kirjoittaisin samalla kielellä mitä he käyttävät. (Peltonen 2004, 204.)

Henkilökohtaiset runot on usein tehty tilauksesta tai jopa asianomaisen itsensä pyynnöstä. Usein miesjoukosta joku pyysi, että "teepä minusta runo". Viina-Matti tai Kalkkimaan pappihan tekivät, mutta yleensä pyytäjä loukkaantui tuotoksen kuultuaan. (Ks. esim. Rentola \& Ritola 1984.) Ajatuksena pilkkarunon pyytäminen itsestä voi olla hauska, mutta käytännössä tuskin kukaan ilahtuu viiltävästä, usein seksuaalisuuteen tai fyysisiin ominaisuuksiin kohdistuvasta pilkasta. (Pilkkarunojen aiheista ks. Vilkuna 2000a, 230.) Pilkkarunon tarkoitushan ei ole imarrella vaan korostaa kohteena olevan todellisia tai oletettuja vajavaisuuksia. Toisaalta sivistyksellisen itsehillinnän ja keskinäisen kontrollin lisääntymisen myötä myös käsityksemme hyvästä mausta on muuttunut. Kun aiemmin mielipiteet lähimmäisen ulkonäöstä esitettiin avoimesti ja poikkeavalle käytökselle naurettiin estoitta, koettaisiin tällainen käytös nykyään loukkaavaksi. (Knuuttila 1992, 268-269.) Näin ollen on vaikea tehdä suoria vertailuja 


\section{Pälvi Rantala}

sen suhteen, miten pilkkarunoihin omana aikanaan suhtauduttiin julkisesti, saatika miten loukkaavina ne sisäisesti koettiin.

Tiettyä henkilöä koskevia avoimen seksuaalisia runoja löytyy etenkin ViinaMatilta. Matti teki rivoja runoja lähinnä maksusta, itse hän ei niistä kertoman mukaan pitänyt. On myös arveltu, ettei Matti esiintyessään halunnut "kuluttaa" pornorunojansa, koska niistä oli hänelle taloudellista hyötyä. Käsityksenä on, ettei Matti itse arvostanut pornorunojaan, mutta sepitti ja lausui niitä, koska seksinnälkäiset miehet halusivat niitä kuulla ja niistä maksaa. Siisti runo maksoi pari markkaa, ruokoton viitosen. (Tirilä 1995, 180.)

Myös Tanholinilta tilattiin häpäiseviä runoja. Runot saattavat äkkiseltään kuulostaa hyvinkin rivoilta ja yksityiskohdissaan jopa hätkähdyttää. Osa niistä luultavasti onkin tehty shokeeraamismielessä: mitä rivompi, sen parempi. Kansanhuumoria tutkinut Seppo Knuuttila toteaa, että karkea puhe ja häpäisevä seksuaalinen pilailu voidaan kyllä kokea humoristiseksi, mutta toisaalta ne torjuvat tehokkaasti pyrkimyksiä eroottisiin virityksiin ja seksuaaliseen kontaktiin. Näin huumorin ja erotiikan suhde on ristiriitainen, ja kiihottavasta on vain lyhyt matka naurettavaan. (Knuuttila 1992, 226-227.)

Toisaalta pilkkaaville, seksuaalissävytteisille runoille oli tilausta viihdyttävässä ja opettavaisessa mielessä. Pilkkalaulut liittyivät myös kiusoittelulaulujen perinteeseen. Matti Hako on todennut, että kyläyhteisön tyttö- ja poikaryhmät lauloivat yhteisissä tapaamisissa lauluja, jotka saattoivat olla hyvin realistisia tai rehvastelevia ja lisäksi avoimen seksuaalisia. Sukupuolten välinen ärsyttely keskittyi tavallisesti tyttöjä ja näiden siveyttä moralisoivaan propagandaan tai poikien saamattomuuteen tai ulkomuotoon. Kiusoittelulaulujen aiheina olivat tavallisesti naimattomien nuorten suhteet: piikittelynhalu, mustasukkaisuus, onneton rakkaus ja solvattu itsetunto. (Hako 1963, 434-435.) Esimerkiksi Tanholinilta tilasivat runoja rengit, joita piika ei ollut päästänyt aittaansa (Möttönen \& Tuohimetsä 1980; Möttönen 2005, 28). Runojen tilaajia olivatkin useimmiten miehet - yhtään naisen tilaamaa runoa ei analysoimieni runojen joukkoon mahdu.

Tanholin ja Viina-Matti ilmeisesti tienasivat ainakin osan elannostaan tekemillään runoilla, vaikka Laurila mainitseekin $(1956,121)$ Tanholinin lopettaneen runojen teon, kun joku oli huomauttanut ansaitsemistavan arvottomuudesta. Kalkkimaan papille taas maksettiin siitä, ettei hän olisi esittänyt lauluja. Tällaisia tapauksia tunnetaan ainakin muutama, ja yleensä laulun kohteena oli herrasneiti tai sahapohatta Anders Kurth. "Antti Kurtti Kuusamosta, Pitkän Liisan poika" on edelleen tunnettu hokema, jonka kerrotaan sisältyneen Kalkkimaan papin sepittämään pilkkaavaan runoon. Kurtin kerrotaan maksaneen Kalkkimaan papille, jottei tämä olisi esittänyt laulua julkisesti. Pitäjän mahtimies olisi voinut ohittaa kerjäläisen pilkan, mutta säilyttääkseen kunniansa ja maineensa hän kuitenkin katsoi tarpeelliseksi estää runon leviämisen. (Esim. SKSÄ 31, 1973.) Runo tuskin olisi vahingoittanut rikkaan miehen mainetta, mutta yhteisölle tällaiset kertomukset ovat tärkeitä: kenties runo ja kertomus siitä ilmaisevat niitä tunteita, joita Kurtti henkilönä tai hänen asemassaan oleva herätti.

Osa seksuaaliaiheisista runoista on ilmeisesti tehty opetus- tai paljastustarkoituksessa, tietoisena tavoitteena osoittaa, että "tiedän mitä teit viime kesänä". 


\section{AMMATTINA PILKKARUNOILJA}

Pahat - tai muutkaan - teot eivät jää salaisuudeksi. Tällaisena voisi tulkita Viina-Matin runon Rito-Nikusta:

Sorakielinen sorikka, isovärk.kinen itikka, mustasukeanen mutikeka, buorabäntänen butikeka, piti naista narrinansa, ibmislasta ilonansa. Houkka houkutti hupakon heinälatoon helluksensa pannaksensa piika parkaa. Piika parkasi pahasti pubjetessa immenkalvon.

[..] Pian oli piika kantavana, papin amen pantavana.

(Viinamaa 1968.)

Satu Apo toteaa, että juorut ja henkilötarinat toimivat yhteisön kannalta sosiaalisen kontrollin välineenä. Ne muistuttivat, että on syytä elää normien mukaisesti, ettei joutuisi julkisuuteen, sananalaiseksi. Häpäisevien kertomusten tehoa lisäsi Apon mukaan se, että ne saatettiin kiteyttää runomittaiseksi. (Apo 1989; ks. myös Huldén 1974,180.) Näin pilkkarunoilijat toimivat yhteisössään myös moraalinvartijoina.

Tilattuihin paljastusrunoihin lukeutuu myös Vihta-Paavon runo Maaningan papista. Maaningan miehet olivat suivaantuneet pappinsa huonoihin tapoihin ja kävivät runoilijalle asiasta kertomassa. Paavon kerrotaan miettineen yön yli, ja aamulla monisäkeinen laulu oli valmis.

Saatana on siansa saanut, Juntas julkisen elannon,

Sielun paimenet pilanna, Syntibin syvälle vienyt,

Huoruutehen baikiahan.

(Makkonen 2001, 283.)

Kaikki tilauksesta tehdyt runot eivät suinkaan ole rivoja tai hävyttömiä. Tanholinista kerrotaan:

Jos talollinen vihastuu naapuriinsa, hän kääntyy Tanholinin puoleen. Jos kosija jää toiseksi, hän hakee apua kostolleen Tanholinilta. [..] Joissakin kirjallisissa pilkkarunopyynnöissä kuvaillaan riitakaverin ulkonäköä tai luonteenpiirteitä, jotka tilaustyössä pyydetään ottamaan huomioon. (Möttönen \& Tuohimetsä 1980.)

\section{JOS EI SITÄ HYVIN KOHDELTU, SE TEKI LAULUN: SPONTAANIT VIHASTUMISRUNOT}

Toisen ryhmän muodostavat tietyssä tilanteessa, yleensä pikaistuksissa tekaistut runot. Spontaanisti syntyneet pilkkarunot kohdistuivat siihen, joka ei kohdellut runoilijaa tämän odottamalla tavalla tai joka muuten vain sattui ärsyttämään sillä hetkellä. Pilkkarunojen kohteena ovat herrat, vallesmannit ja papit, mutta myös muu väki: naapurit, piiat, rengit, kauppiaat, emännät ja sahapohatat. Kukaan runoilijoista ei tunnu 


\section{Pälvi Rantala}

valikoineen kohteitaan tai poteneen erityistä herravihaa, päinvastoin heidän pilkkaansa voisi kutsua tasa-arvoiseksi sekä sukupuolen että sosiaalisen aseman suhteen. (Vrt. Lehtola 1992; Vilkuna 2000b, 41; ks. Apo 1995, 150.) Tilanteessa syntyneissä runoissa näkyy runoilijoiden verbaalinen lahjakkuus, ja niitä lukiessa myös ymmärtää, miksi heitä pelättiin. Näissä runoissa konkretisoituvat heikon valta ja sanan mahti, ja niiden voimakkuus välittyy myös nykylukijalle. Vaikka runojen sisällöt alkavat olla jo kaukaisen tuntuisia kuvauksia ihmisistä, jotka ovat meille vieraita, on se sosiaalinen tilanne, jossa ne ovat syntyneet, hyvinkin tunnistettavissa. Runoissa ja tilanteissa, joissa niiden kerrotaan syntyneen, näkyvät pienoismuodossa sosiaaliset verkostot, valtarakenteet ja yhteisössä käytävä peli.

Pilkan vakavuudesta ja maineen pitkäaikaisesta menetyksestä kertoo se, että runoilijaa varottiin loukkaamasta, koska tämä saattoi pyöräyttää loukkaajasta halventavan ja naurettavan runon, jolloin elämä olisi saattanut olla pilalla pitkänkin iän loppuun saakka (ks. Tirilä 1995, 179). Matti Kuusi on kirjoittanut 1600-luvun pilkkalaulusta: "Kappalaisen rouva valitti, että häväistysruno oli levinnyt, kuten yleisesti tiedettiin, niin laajalle, että hän oli tullut pahaan huutoon muuallakin hiippakunnassa." (Kuusi 1965, 199.) Kalkkimaan papista sanotaan, että "sitä oli pitäny passata niinko piispaa pappilassa, net olhet tohtinhet kukhan huonosti hoitaa", muuten tämä oli tehnyt pilkkalaulun ja niin oli talon maine mennyt (SKSÄ 253, 1973). Runo saattoi syntyä tilanteessa, jossa kulkuri ei saanut ruokaa tarpeeksi nopeasti, ruoka ei ollut mieleistä, runoilijaa ei ollut muiden lailla kutsuttu juhliin tai yösija talossa jäi saamatta. Uuno Hannula kertoo Kalkkimaan papin kiukustuneen Loviisa-nimiselle hieman kyssyselkäiselle piialle, joka ei kyllin nopeasti laittanut tälle ruokaa:

$$
\begin{aligned}
& \text { Luppa, joll'on selässä kuppa, } \\
& \text { Sït' ei huoli kukhaan mukhaan, } \\
& \text { Se kulluu aivan hukhaan. } \\
& \text { (SKS, KIA PK 6.5.1914.) }
\end{aligned}
$$

Tanholin taas pyysi avustusta vastaan tulleelta papilta, ja kun tämä ei suostunut, esitti runoilija oman näkemyksensä hengenmiehestä:

On sillä nuottia, on sillä ääntä / on sillä vaivaa, kun päätänsä kääntää,
herraa kumartamalla pybinä saarnaa Jumalan sanaa
kuolleet siunaa ja elävät manaa.
On palkekana maallinen raha, kun nöyrille taivaassa tanssia takaa,
kuusi päivää viikossa mässää ja makaa, kasvattaa kaarevaa mabaa.
Pystyssä noituu, itkee ja huokaa / sairaille sieluille rukoilee ruokaa,
parit vihkii ja lapset kastaa, kun vaan kansa saatavat maksaa.
(Möttönen \& Tuohimetsä 1980.)

Vihta-Paavon asema yhteisössään oli huomattavasti arvostetumpi kuin muiden pilkkarunoilijoiden, mutta myös häntä pelättiin runojensa vuoksi. Kerran hän oli yöpymispaikassaan kestikievaritalossa mennyt nauttimaan pöydän antimista. Kun hänet kovakouraisesti talutettiin ovelle, teki Paavo laulun: 


\title{
AMMATTINA PILKKARUNOILJA
}

\author{
Kovan onnen koukekunokka \\ ilkesit kun itseäsi viisahamman Vibta-Paavon \\ ulos viskata ovesta.
}

(Haavio 1923, 12-14; Makkonen 2001, 31.)

Kun vieraan henkilöllisyys selvisi, isäntä vei hänet kutsuvieraana pöytään peläten, että Vihta-Paavo tekisi isäntäväestä pilkkarunon. Vieraan kerrotaan hauskuttaneen vieraita laulullaan myöhään yöhön. (Haavio 1923, 12-14; Makkonen 2001, 31.)

Pilkkarunoilija saattoi käyttää taitoaan ja omaa omituista rooliaan myös hyödyksi kiperissä tilanteissa: kun santarmi pidätti Viina-Matin, tämä alkoi ladella pilkkarunoa. Kalkkimaan papilta taas tuomari kysyi oikeudessa, että miten ne runot syntyvät. Tämä vastasi: "Linnut ne lentää ilmassa, kalat ne asuu veessä, ja minun raukan seisoa täytyy tuomaritten eessä.” Tuomari päätti antaa miehen mennä. (SKSÄ 31, 1973.) Näitä tapauksia ei ehkä koskaan todellisuudessa ole sattunut, mutta sekin kertoo jotain, että ne elävät yhteisössä: verbaalista lahjakkuutta ihaillaan, se on merkki selviytymiskyvystä ja tilannetajusta.

Kielen avulla pilkkarunoilijat käyttävät "heikkojen valtaa": marginaalissa olevien, tilattomien, talottomien, rahattomien (Åkesson 1996, 183). Kaikki pilkkarunoilijat eivät toki olleet köyhiä marginaalissa eläjiä, mutta silti useita heistä voitaneen verrata kylähulluihin tai -originelleihin, jotka käyttivät paikallisyhteisön eliittiin kohdistuvaa valtaa ja vastarintaa. Heidän asemansa ei kuitenkaan ollut vain ihailtu ja harmiton: marginalisoidun rooli saattaa olla myös yksinäinen ja väärinymmärretty. (Åkesson 1996, 178-180; ks. myös Rantala 2003.) Mutta oli pilkkarunoilijoiden valta ja vastarinta yhteisössä todellista tai ei, kenties heidän esittämällään pilkalla silti on emansipoiva vaikutus - jos ei omana aikanaan niin ainakin jälkikäteen.

\section{KRITIIKIN SANA, KRIITIKON RUNO: YHTEISKUNNALLISET KANNANOTOT}

Kolmantena pilkkarunojen ryhmänä ovat yhteiskunnallisiksi kannanotoiksi luokiteltavat runot, joiden syntytilannetta ei yleensä tiedetä. Pilkkarunoilijat ottivat aktiivisesti kantaa niin omaa yhteisöään ja ympäristöä koskeviin asioihin kuin yleisemmin maailmassa vallitsevaan tilanteeseenkin. (Runojen aiheista ks. esim. Haavio 1923; Piela 1997.) Kaikki neljä miestä olivat lukutaitoisia, laajasti asioista kiinnostuneita ja myös seurasivat maailman tapahtumia aktiivisesti. Näissä runoissa pilkka ei kohdistu tiettyyn henkilöön vaan yleiseen tilanteeseen, johonkin ammatti- tai sosiaaliseen ryhmään tai ilmiöön.

1800-luvulla tiedonvälitys oli pääosin suullista, ja suurimman osan niin oman kulmakunnan kuin kaukaisten seutujenkin asioita koskevista tiedoista maaseudun ihmiset kuulivat kirkonkuulutuksista, kaupunkimatkoilla ja väen kokoontumispaikoilla (Heikkinen 1987, 119-122; Tommila 1986, 22-26). Näin ollen pilkkarunot toimivat 


\title{
Pälvi Rantala
}

myös tiedon välityksenä muulle yhteisölle, esittiväthän ainakin Kalkkimaan pappi ja Viina-Matti runojaan siellä, missä ihmiset olivat koolla: markkinoilla, kirkonmäellä ja käräjäpaikoilla. Runot, laulut ja veisut levisivät muistinvaraisesti tai käsin kirjoitettuna, joskus painettunakin, suurenkin joukon tietoisuuteen (ks. Heikkinen 1993, 93-99).

Runoilijat pohtivat myös yhteiskunnallista hierarkiaa, sosiaalista rakennetta ja omaa asemaansa siinä. Juho Tanholin tuskailee, ettei köyhälle sallita edes naimista:

\section{[..] Mikä on vietävä vikana / joko on nielussa nikama, kun ei anneta avata / poikki lattian ravata, lisätä sitä sukua / joka on velliä vahissa, säkkki käessä kärkkymässä joka kylän kynnykesellä. (Möttönen \& Tuohimetsä 1980.)}

Kalkkimaan papin kielellisesti parhaisiin lukeutuva runo Herrat ja virkavalta on esimerkki hänen yhteiskuntakritiikistään:

\author{
Suuret herrat on susia / pienet herrat on piruja \\ fouvit kaikeki bäijyjä / fallesmannit feeliä \\ ja komisaariukset koiria. \\ Kun joku köybä knokekïpi / se rubtinaatki ruokkiipi \\ Sekä suuret senaatit / korkeimmatki kenraalit. \\ Talonpoika kun talon ostaa / pienelä rahalansa \\ nïn herrat heti syöhmän alkaa / suurela mahalansa. \\ Kuoleman hauta on syvä / ja köybile pittää olla byvä. \\ (Lehtola 1992; Oukka 1976, 75.)
}

Huonosti käyttäytyvät tai asemaansa väärin käyttävät papit ja virkamiehet saavat kuulla kunniansa useassa runossa, samoin köyhän kansan viljan vievä yläluokka. Nämä runot kohdistuvat usein tiettyyn henkilöön, kuten seurakunnan pastoriin tai keisari Nikolaihin. Runojen alkusysäyksenä saattaa olla itse koettu vääryys, mutta useiden voi ajatella kuvastavan myös runoilijan lähiyhteisön tunteita laajemminkin. Tässä mielessä heitä voi pitää asioiden julkituojina, sanansaattajina tai sanomakelloina.

Monissa runoissa näkyy siveettömyyden tai "huonon elämän" paheksunta. Paheksunnan, jopa moralisoinnin kohteena ovat niin koreilunhalu, viinanjuonti kuin seksuaalinen riettailu. Tämäntyyppisiä runoja on eniten Kalkkimaan papilla ja ViinaMatilla. Kalkkipappi suomii kovalla sanalla kapakan emäntää ja tämän luona mässääviä ja juopottelevia herroja, tyttöjä, jotka naivat venäläisiä, ja tansseissa kulkevia tyttöjä. Myös Viina-Matti arvostelee tanssiharrastusta ja viinankeittoa. Lisäksi huonoa kasvatusta antaneet äidit joutuvat runoon mukaan.

Vaikka pilkkarunoilijat arvostelivat maailman ilmiöitä, yhteisön jäseniä ja vallanpitäjiä, ei heidän pilkkansa kuitenkaan pyrkinyt muuttamaan vallitsevaa tilannetta. Näin ollen heitä ei pyritty myöskään vaientamaan eikä koettu uhkaksi vallitsevalle järjestykselle. Satu Apo on todennut, että positiiviset yhteiskunnalliset utopiat, joissa haaveillaan laajojen ihmisryhmien aseman parantamisesta, ovat kehittyneet useimmiten muualla kuin enimmältään suulliseen perinteeseen tukeutuvissa yhteiskunta- 


\section{AMMATTINA PILKKARUNOILIJA}

kerrostumissa (Apo 1989, 120). Pilkkarunoilijat eivät olleet kansankiihottajia eivätkä runoillaan tähdänneet pysyvään muutokseen. Pikemminkin tavoitteena oli hetkeksi, karnevaalin tapaan, kääntää roolit päälaelleen tai tuoda näkymätön näkyviin. (Ks. esim. Alho 1988; Eco 1984; Palmenfelt 1996, 16.)

\section{PilkKarunOILIJa YhteisössäÄN}

Perinteentutkimuksen näkökulmasta pilkkarunoilijoiden paikka oli pitkään marginaalissa tai välitilassa. Heidän runonsa eivät olleet aitoa kansanperinnettä, mutta eivät myöskään taiderunouteen verrattavia tuotoksia. Ne olivat arvostelijoiden silmissä ontuvia, kömpelöitä ja rappeutumista osoittavia tekeleitä, muodoltaan ja sisällöltään arvottomia. Myöhempi perinteentutkimus on nostanut tutkimuskohteeksi myös yksilöllistä ja arkista elämää koskevaa perinnettä, ja myös välimaastoon sijoittuvista, esimerkiksi kansankirjoittajien teksteistä on löydetty uusia, kiinnostavia tutkimuksen aiheita. Näkökulman muutos on siis mahdollistanut uusien lähteiden käytön, mutta myös perinteisten lähteiden tarkastelun uusin silmin. Sama paradigman muutos yleisestä yksityiseen ja toisaalta myös arkipäiväisten, "pienten" mutta kiteytyneiden tutkimuskohteiden ja -aineistojen legitiimiys näkyy myös esimerkiksi omissa kotitieteissäni sosiologiassa ja kulttuurihistoriassa.

Pilkkarunoilijoiden ja etenkin heidän runojensa asema "marginaalissa" on ollut pitkälti akateemisten, koulutettujen tutkijoiden luoma käsitys näiden runojen arvosta. Maaseudun runoilijoiden paikka yhteisössään tuskin on ollut juurikaan kytköksissä siihen, mitä Helsingin oppineet näistä ovat ajatelleet ja miten he ovat runoja arvioineet. Runojen ensisijainen yleisö ei ole ollut oppineiden piiri vaan ne ihmiset, joiden joukossa runoilijat elivät, heidän paikallisyhteisönsä. Runot ovat myös pääosin säilyneet paikallisten ihmisten ylläpitämänä suullisena perinteenä. Joitain runoja on tekijä itse tai joku muu merkinnyt muistiin, vain harvoin on ulkopuolinen perinteenkerääjä sattunut paikalle kirjoittamaan runoa muistiin sen esityshetkellä. Pilkkarunoja ovat toki tallettaneet myös esimerkiksi paikallisesta perinteestä kiinnostuneet ylioppilaat ja SKS: $\mathrm{n}$ kerääjät, mutta silloin niiden esityskonteksti on yleensä jo unohtunut tai siihen ei ole kiinnitetty juurikaan huomiota. Suullisena perinteenä on kuitenkin välittynyt tieto tai oletus runojen synnystä, ja tuo tieto on sittemmin siirretty kirjalliseen muotoon. Näin voidaan tehdä mahdollisia tulkintoja siitä, millaisessa asemassa runot ja niiden tekijät ovat olleet yhteisössään. Tässä artikkelissa esitän joitain mahdollisia tulkintoja, jatkossa olisi kiinnostavaa analysoida runoja esimerkiksi sukupuolen näkökulmasta.

Pilkkarunoilijoille runoilu oli sekä itseilmaisua, elannon hankkimista että sosiaalista toimintaa. He tarvitsivat yhteisöään kuulijaksi ja runojen maksajaksi yhtä lailla kuin yhteisö tarvitsi heitä. Heiltä tilattiin runoja, kun haluttiin vastata terävästi loukkaukseen tai häpäistä kiistakumppania. Runot toimivat myös viihdykkeenä esimerkiksi metsätöissä odotellessa, kirkonmäellä, iltaa istuttaessa ja juopoteltaessa. Runojen voi ajatella toimineen myös tiedon välittäjinä, moraalisten neuvojen konkretisoijina, suhteiden säätelijöinä ja normien ilmituoijina. Useissa kertomuksissa tulee esiin se, että pilkkarunoilijoita kohdeltiin hyvin, koska heidän tekemiään runoja pelättiin. Tämä osoit- 


\section{Pälvi Rantala}

taa runon voimaa: se saattoi levitä hyvinkin laajalle, säilyä ihmisten muistissa pitkään ja mustata pilkattavan maineen. Pilkkaruno oli siis myös vallankäytön väline.

Pilkkarunojen tekeminen ja esittäminen oli runoilijalle myös vaikuttamisen väylä: muilla tavoilla he tuskin olisivat saaneet ääntään kuuluviin. Toisaalta he eivät olleet yhteisön kannalta liian vaarallisia. He eivät ryhtyneet vaatimaan muutosta vallitsevaan olotilaan, pikemminkin toivat runoillaan hetken helpotusta ja mahdollisuuden nähdä asiat toisin. Huumori ja viihdyttäminen saattoivat olla myös joukosta poikkeavan henkilön keino selvitä yhteisön asettamista paineista. Tanholinin sairaalloisuus, Kalkkimaan papin outo käytös ja Viina-Matin omituisuus toisaalta korostuivat ja toisaalta unohdettiin heidän ladellessaan pilkkarunoja. Tuija Saarinen on kyläsuutari ja -originelli Heikan Jussista todennut, että roolin omaksuminen ja huumori saattoivat olla Jussille keinoja, joilla selvisi vaikean sairauden ja rujon ulkonäön aiheuttamista paineista. Pilkan kohteeksi joutuva ajatteli kenties välttävänsä pilkan pilkkaamalla itse (Saarinen 2000, 97; myös Åkesson 1996, 183).

Pilkkarunoilija esiintyi useimmiten tietoisesti roolinsa valinneena viihdyttäjänä, hän kontrolloi yhteiskunnallista rooliaan ja itseään. Hänellä oli taito verbaaliseen esiintymiseen, hän ymmärsi ajoituksen ja kontekstin merkityksen - ellei tietoisesti, niin intuitiivisesti. Runoille nauraessaan yleisö ei nauranut runoilijalle, vaan tämän jutuille tai esitykselle, ja mukana oli yleensä myös ihailua. (Alho 1996, 29-31.) Pilkkarunoilijat voi nähdä oman yhteisönsä narreina, hierarkian päälaelleen kääntäjinä ja herrojen pilkkaajina. Narrin kaavun alta voi päästellä totuuksia, mutta kuten lasten suusta ei aina kuulekaan totuutta, totuuden puhujakaan ei välttämättä aina ole oikeassa. Ehkä narrin kaavun alta voi päästellä myös valheita ja törkeyksiä tarvitsematta pelätä seurauksia.

Pilkkarunot olivat myös aikansa tiedonvälitystä. Kaikkien neljän runoilijan aikaan suullinen viestintä oli maaseudulla ensisijaista. Tässä kontekstissa runot myös saavat toisenlaisen merkityksen kuin osana perinteenkerääjien kokoelmia, missä ne usein esiintyvät irrotettuina siitä sosiaalisesta yhteydestä, jossa ne ovat syntyneet. Runojen pilkkaamat tapahtumat ja henkilöt ovat olleet osa oman aikansa todellisuutta, ja runot ovat saaneet elinvoimansa juuri sen vuoksi, että niiden aiheet ovat olleet yhteisesti jaettuja. Nykylukijalle runojen pilkkaamat henkilöt ja tapahtumat ovat osa mennyttä aikaa, mutta sekä runot että kertomukset niiden synnystä tuovat esiin välähdyksiä siitä, millaista elämä tuolloin on ollut. Ja ehkä niissä voi tunnistaa jotain myös omasta ajastamme.

\section{VIITTEET}

1. Kulttuurihistorian alaan sijoittuva väitöskirjani "Siedetty, muistettu, tarvittu" keskushenkilönä on Kalkkimaan pappi, ja lähteinä käytän kaikkea hänestä olemassa olevaa materiaalia runoista ja kertomuksista viranomaisaineistoihin ja taideteoksiin. 


\section{AMMATTINA PILKKARUNOILJA}

\section{LÄHTEET}

\section{Arkistoaineistot:}

Suomalaisen Kirjallisuuden Seura, kansanrunousarkisto (SKS, KRA).

— E 75. Paulaharju, Samuli: Pakinoita merkillisistä kansanmiehistä. Wiina-Matti.

- Keruuohjeita 1847-1961, 1-24.

- Paulaharju, Samuli 2668-26804, 1935. Wiina-Matti. Kansanrunoilija. Muistiin kirjoittanut Samuli Paulaharju. Oulu 1935.

— SKSÄ 31, 1973. 2-9, 11. Haastateltava mies, s. 1898. Haastattelija Aarne Nyman, 14.3. Kantojärvi, Alatornio.

— SKSÄ 253, 1973. Haastateltava mies, s. 19.4.1893. Haastattelijat Ilkka Komulainen ja Aarne Nyman, 14.12.1973 Tornio.

Suomalaisen Kirjallisuuden Seura, kirjallisuusarkisto (SKS, KIA).

— PK 6.5.1914. KI 4638. A 1103, Uuno Hannula.

\section{Julkaistut tutkimusaineistot:}

CASTRÉN, KAARLO ALFRED 1882: Kalkkimaan pappi. - Suomen ylioppilaskunnan albumi Elias Lönnrotin kunniaksi, Hänen täyttäessään kahdeksankymmentä vuotta. Helsinki: Suomalaisen Kirjallisuuden Seura. [Kirjoitus julkaistu nimimerkillä Linnanen.] HAAVIO, MARTTTI 1923: Paavo Korhosesta, rautalammelaisesta kansanrunoilijasta. Vähäisiä kirjelmiä LI. Helsinki: Suomalaisen Kirjallisuuden Seura.

HOLOPAINEN, TUURE 1995: Matti Wiinamaa - rahvaan runoilija. - Kaltio 51(3): 96-98.

HÄSTESKO F. A. 1914: Kansanrunoilijoita. 5. Juho Tanholin. - Kotiseutu 15(1): $178-181$.

LÖNNROT, ELIAS 1855-1857: Korhonen, Paavo, folkskald, 1775-1840. - Finlands minnesvärde män. Samling af levnadsteckningar. Helsinki: J. C. Frenckell \& Son.

—1908: Några nyare Finska Runo-Författare. - Elias Lönnrots svenska skrifter. Helsinki: Skrifter utgifna av svenska litteratursällskapet i Finland.

- Paavo Korhosen viisikymmentä runoa ja kunsi laulua 1848. Helsinki: Suomalaisen Kirjallisuuden Seura. [Koonnut ja esipuheen kirjoittanut Elias Lönnrot.]

LEHTOLA, VELI-PEKKA 1992: Kalkkimaan pappi. Pilkkakirves vuosisadan takaa. - Uusi Kansanmusiikeki 14(4): 22-23.

MAKKONEN, SIRKKA (toim.) 2001: Vibta-Paavon runot ja laulut. Rautalampi: Vanhan Rautalammin Korhosten sukuseura ry.

MÖTTÖNEN, MARKKU 2005: Jubo Tanholin, munan alhainen kansanrunoilija. Vaajakoski: Juhon kynäpiiri.

MÖTTÖNEN, MARKKU \& TUOHIMETSÄ, PÄIVI 1980: Juho Tanbolinin tuotanto ja elämänvaiheet. Helsinki: Suomalaisen Kirjallisuuden Seura. 


\section{Pälvi Rantala}

OUKKA, ARVID (toim.) 1986: Tornionlaakson kansanperinnettä IV . Tornio: omakustanne.

RENTOLA, LIISA \& RITOLA, AULIS 1984: Wiina-Matti, viisas mies.... Oulu: Kustannusosakeyhtiö Pohjoinen.

TIRILÄ, TAPANI 1995: Muistikuvia Wiina-Matista. - Kaltio 51(5): 179-180.

VIINAMAA, MATTI 1968: Viina-Matin veisuja 1968. Oulu: Pohjoinen. [Toimittanut Hilkka Merikallio.]

VUENTO, PERTTI (toim.)1994: Historiaa ja perimätietoa hïppakuntarajalta: ruotumiesten ja Kalkekipapin turva. Tornio: Vuento, Pertti.

\section{Kirjallisuus}

ALHO, OLLI 1988: Hullunden puolustus ja muita kirjoituksia naurun historiasta. Helsinki: WSOY.

—1996: De löjliga, de roliga och de glada. - Palmenfelt, Ulf (ed.), Humor och kultur. Turku: Nordic Institute of Folklore.

ANTTONEN, PERTTI 1987: Rituaalinen pilkeka länsi-inkeriläisissä kylähä̈ssä. Julkaisematon pro gradu -tutkielma. Helsinki: Helsingin yliopisto.

APO, SATU 1995: Naisen väki. Tutkimuksia suomalaisten kansanomaisesta kulttunrista ja ajattelusta. Helsinki: Hanki ja Jää.

- 1989: Suullisten kertomusten merkitykset: esimerkkejä suomalais-karjalaisesta kansanperinteestä. - Hoikkala, Tommi (toim.), Kieli, kertomus, kulttuuri. Helsinki: Gaudeamus.

ECO, UMBERTO 1984: The Frames of Comic "Freedom". - Sebeok, Thomas A. (ed.), Carnival! Berlin: Mouton Publishers.

FINGERROOS, OUTI 2004: Sisällissodan arkistoidut muistot ja tulkinnan mahdollisuus. - Kurki, Tuulikki (toim.), Kansanrunousarkisto, lukijat ja tulkinnat. Suomalaisen Kirjallisuuden Seuran Toimituksia 1002. Helsinki: Suomalaisen Kirjallisuuden Seura.

HAKO, MATTI 1963: Riimilliset kansanlaulut. - Kuusi, Matti (toim.), Suomen kirjallisuns I. Kirjoittamaton kirjallisuus. Helsinki: Suomalaisen Kirjallisuuden Seura; Otava. HEIKKINEN, ANTERO 1993: Ihminen bistorian rakenteissa. Mikrobistorian näkökulma menneisyyteen. Helsinki: Yliopistopaino.

- 1987: Tiedonvälitys puolikirjallisessa kulttuurissa. - Pulliainen, Kyösti \& Sihvo, Hannes (toim.), Carelia Rediviva. Joensuu: Joensuun yliopisto; Joensuun Yliopiston tukisäätiö; Karjalaisen Kulttuurin Edistämissäätiö.

HULDÉN, LARS 1974: Något om visan som påverkningsmedel. - Häggman, AnnMari (ed.), Visa och visforskning. Meddelanden frän folk.kultursarkivet 3. Skrifter utgivna av svenska litteratursällskapet i Finland nr 463. Helsinki: Svenska litteratursällskapet i Finland.

HÄGGMAN, ANN-MARI (toim.) 1974: Visa och visforskning. Meddelanden frän folkekultursarkivet 3. Skrifter utgivna av svenska litteratursällskapet i Finland nr 463. Helsinki: Svenska litteratursällskapet i Finland. 


\section{AMMATTINA PILKKARUNOILIJA}

KAURANEN, KAISA 2005: Kun kuokka vaihtui kynään. Suomalaisten kirjoitustaidon lähteillä. - Hiidenkivi 23(3): 11-13.

KNUUTTILA, SEPPO 1992: Kansanbunmorin mieli. Kaskut maailmankuvan aineksena. Suomalaisen Kirjallisuuden Seuran toimituksia 554. Helsinki: Suomalaisen Kirjallisuuden Seura.

KUKKONEN, JUKKA \& SIHVO, HANNES (toim.) 1975: Wäinämöisen weljenpojat. Tutkielmia talonpoikaisrunoudesta. Kalevalaseuran vuosikirja 55. Porvoo: WSOY.

KUKKONEN, JUKKA 1975: Talonpoikaisrunoilijat: perinteentaitajia ja propagandisteja 1800-luvulta. - Kukkonen, Jukka \& Sihvo, Hannes (toim.), Wäinämöisen weljenpojat. Tutkielmia talonpoikaisrunoudesta. Kalevalaseuran vuosikirja 55. Porvoo: WSOY.

KURKI, TUULIKKI 2004: Tekstit Kansanrunousarkiston liepeillä. - Kurki, Tuulikki (toim.), Kansanrunousarkisto, lukijat ja tulkinnat. Suomalaisen Kirjallisuuden Seuran Toimituksia 1002. Helsinki: Suomalaisen Kirjallisuuden Seura.

KUUSI, MATTI (toim.) 1963a: Suomen kirjallisuns I. Kirjoittamaton kirjallisuus. Helsinki: Suomalaisen Kirjallisuuden Seura; Otava.

— 1965: Ilomantsilainen häväistysruno vuodelta 1686. - Kalevalaseuran vuosikirja 45. Porvoo-Helsinki: WSOY.

— 1975: Kolme Ruotsin ajan herjavirttä. - Kukkonen, Jukka \& Sihvo, Hannes (toim.), Wä̈nämöisen weljenpojat. Tutkielmia talonpoikaisrunoudesta. Kalevalaseuran vuosikirja 55. Porvoo: WSOY.

LAURILA, VIHTORI 1956: Suomen rabvaan runoniekat sääty-ybteiskunnan aikana. Suomalaisen Kirjallisuuden Seuran Toimituksia 249. Helsinki: Suomalaisen Kirjallisuuden Seura.

LEHTIPURO, OUTI 2003: Voiko perinnettä kerätä? "Maailman suurin Kansanrunousarkisto" ja kansanrunoudentutkimus toistensa haastajina. - Laaksonen, Pekka \& Knuuttila, Seppo \& Piela, Ulla (toim.), Tutkijat kentällä. Kalevalaseuran vuosikirja 82. Helsinki: Suomalaisen Kirjallisuuden Seura.

PALMENFELT, ULF 1996: Inledning. - Palmenfelt, Ulf (ed.), Humor och kultur. Turku: Nordic Institute of folklore.

PELTONEN, ULLA-MAIJA 2004: Kalevalan riemuvuoden kilpakeruu ja hyvän kerääjän käsite. - Kurki, Tuulikki (toim.), Kansanrunousarkisto, lukijat ja tulkinnat. Suomalaisen Kirjallisuuden Seuran Toimituksia 1002. Helsinki: Suomalaisen Kirjallisuuden Seura.

PIELA, ULLA 1997: Talonpoikaisrunot - lauluja arjesta. - Pirta. Kalevalaisten naisten liiton jäsenlebti 36(3): 10-16.

PÖYSÄ, JYRKI \& TIMONEN, SENNI 2004: Kuinka ahkerat muurahaiset saivat kasvot? Henkilökohtaisen tiedon paikka arkiston keruuohjeissa. - Kurki, Tuulikki (toim.), Kansanrunousarkisto, lukijat ja tulkinnat. Suomalaisen Kirjallisuuden Seuran Toimituksia 1002. Helsinki: Suomalaisen Kirjallisuuden Seura.

RANTALA, PÄLVI 2003: Kylähullut kertomuksissa. Rovaniemi: Lapin yliopisto. — 2005a: Pilkkana tyhmäin ja hulluin vain. - Rantala, Pälvi \& Tuominen, Marja (toim.), Rajoilla. Pubeenvuoroja rajojen tutkimisesta ja tutkimuksen rajoista. Rovaniemi: Lapin yliopistokustannus. 


\section{Pälvi Rantala}

— 2005b: Muistakko sie sen Kalkkimaan papin? Tornionlaakson kylähullu muistoissa ja kertomuksissa. - Tuominen, Marja \& Autti, Mervi (toim.), Suuret herrat susia, pienet herrat piruja. Kabdeksan näkökulmaa elettyyn elämään. Rovaniemi: Lapin yliopisto.

SAARINEN, TUIJA 2000: Heikan Jussi. Katsaus kyläsuutarin huumoriin. - Krekola, Jouni \& Salmi-Niklander, Kirsti \& Valenius, Johanna (toim.), Naurava työlä̈nen, naurettava työläinen. Näkökulmia työväen huumorïn. Helsinki: Työväen historian ja perinteen tutkimuksen seura.

SIHVO, HANNES 1975: Kuinka kansan runoniekkaa on kuvattu? - Kukkonen, Jukka \& Sihvo, Hannes (toim.), Wäinämöisen weljenpojat. Tutkielmia talonpoikaisrunoudesta. Kalevalaseuran vuosikirja 55. Porvoo: WSOY.

SIIKALA, ANNA-LEENA 1984: Tarina ja tulkinta. Tutkimus kansankertojista. Suomalaisen Kirjallisuuden Seuran Toimituksia 404. Helsinki: Suomalaisen Kirjallisuuden Seura.

TOMMILA, PÄIVIÖ 1986: Miten ihmiset tiesivät? - Tiede 2000 6(7): 22-26.

VILKUNA, KUSTAA H. J. 2000a: Herotes oli koira: humoristinen puhe rikoksena. - Matikainen Olli (toim.), Rikos historiassa. Jyväskylän historiallinen arkisto 5. Jyväskylä: Jyväskylän historiallinen yhdistys.

— 2000b: Herranperkeleet ja nakumannit. Säätyläistön ja rahvaan välinen ristiriita suomalaisessa kansanomaisessa huumorissa 1550-1850. - Krekola, Jouni \& SalmiNiklander, Kirsti \& Valenius, Johanna (toim.), Naurava työläinen, naurettava työläinen. Näkökulmia työväen hummorïn. Helsinki: Työväen historian ja perinteen tutkimuksen seura.

ÅKESSON, LYNN 1996: Original och obducenter. - Palmenfelt, Ulf (ed.), Humor och kultur. Turku: Nordic Institute of folklore.

YTM Pälvi Rantala toimii tutkijana Lapin yliopistossa "Pohjan tahto" -hankkeessa. Kulttuurihistorian alaan sijoittuva väitöskirja käsittelee kylähulluutta mikrohistoriallisesta näkökulmasta. 